\author{
Michal Radvan \\ Masaryk University, Czech Republic \\ ORCID: 0000-0002-9858-4555 \\ michal.radvan@law.muni.cz
}

\title{
Taxation of Instagram Influencers
}

\section{Opodatkowanie influencerów korzystających z Instagrama}

\begin{abstract}
This scientific article discusses issues related to the taxation of Instagram influencers. Its main objective is to define how the influencers' incomes should be taxed. To achieve this primary purpose, the partial objective is defined to give the list of (legal) cooperation contracts between the marketers and influencers. The hypothesis that there is no need to adopt new specific tax law norms to tax influencers' incomes properly, at least in developed countries, was confirmed. All jurisdictions are taxing influencers' incomes. It is always necessary to focus on the content of the relationship generating influencer's income, as the principle of priority of content over form must be used. The tax liability is influenced only by the tax base. The tax rate and other structural components of the tax remain the same for different types of incomes. Generally, it is always better for the influencer to have a trading license (to be a businessman) than tax his/her incomes as incomes from copyright. Incomes from dependent activities based on labour law contract or occasional incomes are not probable for a typical influencer, and still, the taxation in this way is not really favourable. The novelty of the presented research lies in the fact that no scientific articles deal with the covered issues published so far. The author believes that the article has a cognitive value for both science and practice.
\end{abstract}

Keywords: tax law; taxation; copyright; income; influencer; Instagram

CORRESPONDENCE ADDRESS: Michal Radvan, Ph.D., Associate Professor, Masaryk University, Faculty of Law, Veveří 158/70, 61180 Brno, Czech Republic. 


\section{INTRODUCTION}

Social media play a more and more crucial role in many aspects of our everyday life. At the very beginning, social media were designed primarily for individuals willing to share their feelings, ideas, pictures, videos, etc., with their friends. As the number of people using social networks was growing, it occurred as a perfect tool for both commercial companies and non-business equities to share information about their products and services. Nowadays, it is almost impossible to imagine a political party, public university, local businessman, or multi-national company without its profiles on Facebook, Instagram, Twitter, YouTube, LinkedIn, etc. The ways social networks are to be used and how to use them in the most effective ways are very different, depending on the type of entity, its aims and intentions. While political parties and politicians want to inform possible voters on their programme to get more votes in elections, universities attract students to study at the school, informing students and staff about the news and presenting information to alumni hoping to provide the school with finance.

For businesses, social media are crucial in the area of marketing. Still, a lot of money is spent on traditional marketing on social networks, i.e., the company presents its products, services o brand itself. However, the customers may become apathetic to these advertising messages. Nevertheless, there is another opportunity for marketers: they may use influencers for promotion. The influencers are usually not directly connected with the marketers; at least the customers believe so. As well, the customers may follow favourite influencers; they have confidence in their experience and opinions. They trust that the social media celebrities are using the best product, buying in the best shops, and having style to be followed.

This article discusses issues related to influencers. However, it is impossible to cover all related topics such as marketing, management, psychology, sociology, etc. It is impossible to deal with all social networks. That is why only Instagram is being used as it is one of the two most popular platforms marketers are planning to use for influencer marketing and the fastest growing social network. The article aims at the legal area, especially the tax law. The main objective of the contribution is to define how the influencers' incomes should be taxed. To achieve this primary purpose, the partial objective is defined to give the list of (legal) cooperation contracts between the marketers and influencers. The author intends to demonstrate the influencers' incomes must be taxed as any other income. The hypothesis to be confirmed or disproved is that there is no need to adopt new specific tax law norms to tax influencers' incomes properly. The article does not deal with international aspects of influencers' taxation. The novelty of the presented research lies in the fact that no scientific articles deal with the covered issues published so far. There are, of course, scientific articles dealing with the Instagram influencers from the 
marketing, ${ }^{1}$ technical ${ }^{2}$ or psychological and sociological ${ }^{3}$ perspectives. The only article focused on Instagram from the national tax law viewpoints by S. Şekeroğlu and S. Bilgin ${ }^{4}$ is dealing with Turkish law. S. Kostikidis ${ }^{5}$ and D. Molenaar and H. Grams,${ }^{6}$ in response, then concerns on international tax law. The author believes that the article has a cognitive value for both science and practice.

The article has been divided into three substantive parts. The first one introduces Instagram as an important marketing tool and brings several statistics to prove this statement. The second one describes the ways how the cooperation between the marketers and the influencers starts and takes place in practice and what are the legal relations between them. It is necessary to analyse existing cooperation models as they are essential for the third part dealing with the taxation issues. In fact, three possible ways how to tax influencers' incomes are possible: to tax them as incomes from dependent activities or incomes from independent (business) activities including incomes from intellectual property rights (copyrights) or occasional (irregular) incomes.

\section{METHODOLOGY}

For this research, it is necessary to get adequate knowledge from practice to know how the relationship between marketers and influencers works. The author has decided to hold a structured, guided interview with two influencers to get information on how the initial contact between the marketer and influencer is made, what form of contract they conclude, what are the rights and obligations, etc. He also got information on how to be in touch with the followers and how it influences the incomes of the influencer. Based on this knowledge, it was possible to define private law relationships applicable to the relation between the marketers and influencers.

After that, the classical research methods and techniques developed within the framework of legal sciences were used. An important value of legal knowledge is

1 For example, see M. De Veirman, V. Cauberghe, L. Hudders, Marketing through Instagram Influencers: The Impact of Number of Followers and Product Divergence on Brand Attitude, "International Journal of Advertising" 2017, vol. 36(5), pp. 798-828.

2 For example, see K. Cotter, Playing the Visibility Game: How Digital Influencers and Algorithms Negotiate Influence on Instagram, "New Media and Society" 2019, vol. 21(4), pp. 895-913.

3 For example, see L.V. Casaló, C. Flavián, S. Ibáñez-Sánchez, Influencers on Instagram: Antecedents and Consequences of Opinion Leadership, "Journal of Business Research" 2020, vol. 117(9), pp. 510-519.

4 S. Şekeroğlu, S. Bilgin, Influencer Marketing and Taxation of Influencer in Turkey, [in:] New Trends in Social Sciences, eds. H. Özüdoğru, T. Çetin, H. Kara, Klaipeda 2019, pp. 125-134.

5 S. Kostikidis, Influencer Income and Tax Treaties, "Bulletin for International Taxation" 2020, vol. 74(6), pp. 359-376.

6 D. Molenaar, H. Grams, Influencer Income and Tax Treaties, "Bulletin for International Taxation" 2020, vol. 74(9), pp. 550-555. 
determining the meaning of norms (rules of behaviour) contained in the legislation. Therefore, the formal dogmatic method was used as a primal method. To analyse, interpret and assess the existing tax legislation, it was necessary to apply the rules of legal linguistic interpretation. Later on, it was possible to describe and systemize tax law provisions applicable to the relationships between marketers and influencers. Partially, the comparative method was used to compare the legal regulation of income taxation in individual countries. The synthesis of arguments allowed to formulate the conclusions, confirm or disprove the hypothesis, and possibly offer improvements for the de lege ferenda regulation.

\section{RESEARCH AND DISCUSSION}

\section{Instagram as a marketing tool}

Compared to the other social applications, ${ }^{7}$ Instagram does not have many active users. S. Kemp ${ }^{8}$ states that Facebook, as the top social application, has 2.7 billion monthly active users, while YouTube and WhatsApp have 2 billion and Facebook Messenger and WeChat approx. 1.3 billion. The only other application with more than 1 billion users is Instagram; Instagram's advertising audience reached a total of 1.16 billion people in October 2020. Most users come from the US, India, Brazil, Indonesia, and Russia, while $88 \%$ of Turkish internet users aged 16-64 years are using Instagram. The Instagram penetration by country is significant in most key markets: Spain and Italy $67 \%$, Germany $63 \%$, Russia $61 \%$, US, Australia, and Canada 56\%, UK 53\%, France 50\%, and Japan 39\%. ${ }^{9}$ More than $63 \%$ of Instagram users are people between $18-34$ years. ${ }^{10}$ Their top interests are traveling, music, food and drink, fashion, movies, health and fitness, technology, cosmetics, sports, and news. ${ }^{11}$

For business purposes, it is necessary to have followers: the other uses of Instagram following the profile. More than half of Instagram users have less than 1,000 follower count. The important number of followers for marketers is 10,000 followers. This condition is met by $10 \%$ of Instagram users, while $0.5 \%$ has more

${ }^{7}$ All statistics are taken from M. Iqbal, Instagram Revenue and Usage Statistics (2021), 24.05.2021, www.businessofapps.com/data/instagram-statistics [access: 16.04.2021].

${ }^{8}$ S. Kemp, Digital 2020: October Global Statshot, 20.10.2020, https://datareportal.com/reports/ digital-2020-october-global-statshot [access: 16.04.2021].

${ }_{9}$ M. Iqbal, op. cit.

${ }^{10}$ S. Kemp, op. cit.

${ }^{11}$ Facebook for Business, How to Take Your Instagram Content to the Next Level, 14.02.2019, www.facebook.com/business/news/insights/how-to-take-your-instagram-content-to-the-nextlevel?ref=FBB_ConnectWithNewAudiences [access: 16.04.2021]. 
than 500,000 followers. ${ }^{12}$ The most followed celebrities (influencers) are sportsmen (Cristiano Ronaldo, Lionel Messi), singers (Ariana Grande, Selena Gomez, Beyoncé, Justin Bieber), models (Kylie Jenner, Kim Kardashian West), and actors (Dwayne Johnson), all with more than 150 million followers, while Cristiano Ronaldo has 244 million followers. ${ }^{13}$ The most followed brands are Instagram (382 million followers), National Geographic, NASA, fashion companies (Nike, Victoria's Secret), and accounts connected with sport (Real Madrid, FC Barcelona, UEFA Champion's League, NBA). ${ }^{14}$

Seeing the most popular brands and influencers, it is evident that the most popular industry on Instagram is fashion: the percentage of total Instagram brand interactions is almost $25 \%$. The other important industries are e-commerce, beauty, auto, retail, electronic, services, and sporting goods. ${ }^{15}$ Instagram users ascribe especially popularity, creativity, fun, relevance, and community focus as values to brands on Instagram. ${ }^{16}$ As well, they expect entertaining, authentic, informative, personally relevant, and inspiring content. ${ }^{17}$ The research shows that $79 \%$ of Instagram users search for more information after seeing products and/or services on Instagram, $65 \%$ of them visit the brand website, and $46 \%$ make a purchase. On top of that, $37 \%$ of Instagram users visit a retail store, $31 \%$ follow the brand account, and $29 \%$ speak to someone else about the brand. ${ }^{18}$

All these statistics are excellent for marketers as Instagram marketing using influencers effectively focuses on the target customers and their shopping behaviour. That is why $72 \%$ of brand representatives believe that influencer marketing results in higher quality leads and $66 \%$ of brands planned to increase their influencer marketing spend in $2020 .{ }^{19}$ Marketers can make USD 5.20 for every USD 1 invested in influencer marketing. ${ }^{20}$ More than half $(55 \%)$ of marketers are planning to use

${ }^{12}$ HubSpot, Instagram Engagement Report - What Your Company Needs to Know for 2020, 10.03.2021, https://cdn2.hubspot.net/hubfs/53/HubSpotMention_ebook_2020-FINAL-1.pdf [access: 19.04.2021].

13 Social Blade, Top 50 Instagram Business Accounts Sorted by Followers, https://socialblade. com/instagram/top/50 [access: 19.04.2021].

14 Ibidem.

15 T. Bern, Social Media Trends Report: Key Insights From Q3 2020, www.socialbakers.com/ blog/social-media-trends-report-q3-2020 [access: 19.04.2021].

${ }^{16}$ Facebook for Business, How Instagram Boosts Brands and Drives Sales, 6.02.2019, www. facebook.com/business/news/insights/how-instagram-boosts-brands-and-drives-sales [access: 19.04.2021].

17 Facebook for Business, How to Take Your Instagram Content...

18 Facebook for Business, How Instagram Boosts Brands...

19 Influencer Marketing Hub, The State of Influencer Marketing 2020: Benchmark Report, 14.02.2021, https://influencermarketinghub.com/influencer-marketing-benchmark-report-2020 [access: 19.04.2021].

${ }^{20}$ Ibidem. 
Instagram for influencer marketing in 2021. Only YouTube expects more marketers (58\%), while online advertising is planned by $43 \%$, TV advertising by $29 \%$, and out-of-home advertising by $20 \%$ marketers willing to use influencers. The other social networks planned to use are TikTok (35\%) or Twitch ( $20 \%$ of marketers). ${ }^{21}$ Compared to the other platforms, $18 \%$ of marketers believe Instagram offers the best influencer marketing return on investments (ROI), which is the same as YouTube and only $3 \%$ less than online advertising..$^{22}$ In the end, 39\% of brands spend over $20 \%$ of their marketing budget on influencer marketing.

Table 1. How much do brands spend on influencer marketing?

\begin{tabular}{|c|c|}
\hline Proportion of marketing budget & Proportion of brands \\
\hline$<10 \%$ & $22 \%$ \\
\hline $10-20 \%$ & $39 \%$ \\
\hline $20-30 \%$ & $23 \%$ \\
\hline $30-40 \%$ & $7 \%$ \\
\hline $40 \%+$ & $9 \%$ \\
\hline
\end{tabular}

Source: Influencer Marketing Hub, The State of Influencer Marketing 2020: Benchmark Report, 14.02.2021, https:// influencermarketinghub.com/influencer-marketing-benchmark-report-2020 [access: 19.04.2021].

More than half (51\%) of brands work with less than 10 influencers, while 5\% of brands cooperate with 100-1,000 influencers and 3\% of brands work with more than 1,000 influencers. Dwayne "The Rock" Johnson, who charges on average USD 1,015,000 per post, is the most expensive celebrity. ${ }^{23}$ However, the number of followers nor the price per post does not mean marketing effectiveness as the effectiveness measures number of followers, interactions per followers, and posting activity. That is why the most effective brand influencers are generally unknown persons having a very different number of followers and interactions.

Table 2. Most-effective brand influencers in Q3 2020

\begin{tabular}{|l|c|c|}
\hline \multicolumn{1}{|c|}{ Influencer } & Followers & Interactions \\
\hline Mridul Sharma & 98,600 & $1,247,300$ \\
\hline Julie Ferrat & 165,700 & $1,024,000$ \\
\hline Pamela Pedroza & 13,500 & 591,500 \\
\hline Kanaan Pitan & 54,700 & 483,000 \\
\hline Lauren Kettering & 843,900 & $8,077,800$ \\
\hline Samira Ahmed & 106,200 & 604,600 \\
\hline
\end{tabular}

Source: T. Bern, Social Media Trends Report: Key Insights From Q3 2020, www.socialbakers.com/blog/social-media-trends-report-q3-2020 [access: 19.04.2021].

${ }^{21}$ Takumi, Into the Mainstream: Influencer Marketing in Society, https://takumi.com/whitepaper2020 [access: 19.04.2021].

22 Ibidem.

${ }^{23}$ Hopper HW, Instagram Rich List 2020, 19.04.2021, www.hopperhq.com/blog/instagram-rich-list [access: 19.04.2021]. 
The effectiveness depends as well on the promoted industry: while the health care industry has on average 4.2 interactions per brand post, airlines have only 0.2 average interactions per brand post. In these circumstances, the top industries are (besides health care) finance, telecommunications, and accommodations, while the weakest are not only airlines but the sporting goods and car industry, too. ${ }^{24}$ The brands most mentioned by Instagram influencers are IDeal of Sweden, Walmart, Pretty Little Thing, Question Nutrition, Michelob Ultra, and L'Oréal Paris. ${ }^{25}$

Companies - marketers are aware of the influencers' power in marketing. For example, a total US and Canada influencer spend by quarter has almost tripled in Q4 2019 to USD 434 million from USD 163 million in Q1 2018. ${ }^{26}$ The top ten brands spent almost USD 112 million on influencer marketing in the US and Canada in 2019. ${ }^{27}$ Instagram itself, as a strong marketing platform, increased its net advertising revenue (after traffic acquisition costs paid to partner sites) from USD 1.61 billion in 2016 to an estimated USD 15.65 billion in $2021 .{ }^{28}$ To conclude, influencer marketing seems to be one of the most essential marketing tools for marketers. Global spend on influencer marketing is predicted to be worth somewhere between USD 5 billion and USD 10 billion by 2020 and rising as high as USD 15 billion by $2022 .{ }^{29}$

\section{Models of cooperation between the marketers and the influencers}

The structured, guided interview with two influencers allowed the author to get information on how the initial contact between the marketer and influencer is made, what form of contract they conclude, what are the rights and obligations, etc. Both influencers are ladies between 25 and 30 years old. They are studying and working at the same time. However, the first one is running her own business with hygienic products for women, while the second one is working in the law firm and works as

24 T. Bern, State of Influencer Marketing Report: Effects of Coronavirus, www.socialbakers. com/blog/influencer-marketing-report [access: 19.04.2021].

25 Idem, Social Media Trends Report...

26 J. Ghatt, Report: Top Brands Spent \$255M on Influencers with Fake Engagement, 5.03.2020, https://jenebaspeaks.com/2020/03/report-top-brands-spent-255m-on-influencers-with-fake-engagement [access: 19.04.2021].

27 A. McClendon, It's estimated that Fashion Nova spent \$40M on influencer marketing last year, 2.03.2020, https://twitter.com/faintflex/status/1234272114808696834?ref src=twsrc $\% 5 \mathrm{Etf}$ w\%7Ctwcamp\%5Etweetembed\%7Ctwterm\%5E1234272114808696834\%7Ctwgr\%5E\%7Ctwcon $\% 5$ Es1_\&ref_url=https $\% 3 \mathrm{~A} \% 2 \mathrm{~F} \% 2 \mathrm{Fwww}$. complex.com $\% 2 \mathrm{Fstyle} \% 2 \mathrm{~F} 2020 \% 2 \mathrm{~F} 03 \% 2 \mathrm{Ffashion}$-nova-spent-40-million-dollars-influencer-marketing-2019 [access: 19.04.2021].

28 B. Droesch, Instagram's New Explore Ads Signal Potential Changes to Organic Reach, 9.07.2019, www.emarketer.com/content/instagrams-new-explore-ads-signal-potential-changes-to-organic-reach [access: 19.04.2021].

29 Mediakix, The Influencer Marketing Trends to Know for 2021, 17.04.2021, https://mediakix. com/influencer-marketing-resources/influencer-marketing-trends [access: 19.04.2021]. 
a fashion model. For both of them, the incomes from influencing activities are only supplementary. The first lady had her small groups of customers who followed her on Instagram mainly because of her main product. She decided to offer them other more or less related products: mainly cosmetics and clothes. At the moment, she has approx. 8,000 followers. Most of them are independent married ladies from the Czech Republic with above-average incomes. The second interviewed influencer posts mainly sexy pictures as she is using Instagram as a platform to offer herself as a model. She has over 48,000 followers. However, these are primarily men from all over the world who want to see her new posts and videos; they are not willing to buy any products and services such as a gym or food supplements she is (rarely) promoting.

From the examples mentioned above, it is evident that the number of followers is not essential for the incomes of the influencer. More crucial is the "quality" and activity of followers; they must be materially secured. They have to follow the influencer because of products or services she/he promotes and have to follow the influencer regularly, ideally every day. That might be the reason why the incomes generated by both interviewed influencers are almost the same.

Both influencers gave the same examples of cooperation (private law relationships applicable to the relation) between the influencer and the marketer. They both stated that it is not probable that there would be any labour law relationship between the parties; however, they were not able to tell the reasons. In the author's opinion, the reason might be practical: the influencer is relatively free on the marketer, she/ he does not have to follow the marketer's commands. The cooperation might be only one-time or irregular. The income taxes are generally higher for employees than self-employed persons, and there are additional social and health contributions to be paid. On the other hand, there might be cases of influencers employed by marketers. For example, if the influencer is working for the marketer for some time in a different position, and while promoting his/her products and services effectively, the working position is changed.

The most common type of cooperation between the influencer and the marketer is a barter: the marketer contacts the influencer by email or via Instagram, offering some products or services at a specific value (but free for the influencer) for testing. The products or services are very different, from clothes and cosmetics to holidays. As well, the value might differ a lot; in the case of higher values (e.g., a car), the influencer gets right to use it only for a certain time and she/he has to return it back and is not allowed to keep it. A specific type of barter is a trip to an interesting destination to see the presentation of new products, while the marketer pays the travelling costs. The marketer specifies what she/he demands in return: product or service review in the form of several stories, posts, etc. The marketer often adds discount coupons for the customers (codes) to be connected to the post.

If the barter cooperation works well, the next step is the cooperation contract - the marketing representation. The influencer becomes the ambassador of the 
brand. It means, e.g., that the marketer sends the clothes collection four times a year at a higher value and asks for more posts with hashtags or phrases in return. Sometimes, the influencer has to send pictures with the products to the marketer, who is free to use them in his marketing campaigns. The best ambassadors may get additional products as gifts. However, the question is whether it is really a gift when they boast of it on Instagram, mentioning the marketer.

The second interviewed influencer mentioned an additional type of barter cooperation typical for models. When she was photographed to promote a collection of clothes for a financial reward, she can keep it under the condition she uses some pictures as posts on her Instagram.

As stated above, the marketer may give the influencer a unique code to be connected to the post serving as a discount voucher for customers. The code is connected with the influencer's name and the influencer gets additional money every month as a share of the price (5-20\%) for the customer. This practice is called affiliate marketing. ${ }^{30}$

The most popular influencers are not interested in barters and they get direct payments for their posts. As obvious from the text above, the worldwide known celebrities get more than USD 1 million per post, while local superstars get USD 5,000 at maximum.

Sometimes, suppose the influencer does not respond to the marketer's offer (especially in the case of celebrities). In that case, the marketer sends the product (primarily cosmetics) to the influencer without a previous contract. If the influencer does not make promotion and does not send the product back, the product might be seen as a gift.

To conclude, besides rare labour law relationships, there are several possibilities of civil law contracts between the marketer and the influencer. It will probably be an innominate contract, close to a contract of work, or specifically the contract of work. By a contract for work, the influencer (contractor) undertakes to perform work, at his/her own expense and risk, for the marketer (client), and the marketer undertakes to take over the work and pay the price.

The other possibility is a license as many posts and stories result from human creation, namely creation that falls under creative or artistic activity; the influencer is free to create and combine creative elements. ${ }^{31}$ The findings of the Court of Justice of the European Union ${ }^{32}$ also stated that the author's own intellectual creation must bear the "seal of his/her personality", and through individual decisions made within the framework of creative freedom, the author can "imprint his personal

${ }^{30}$ K. Kůdelíková, Skrytá reklama na sociálních sitích-diplomová práce, Brno 2020, p. 55.

${ }_{31}$ P. Koukal, Autorské právo, public domain a lidská práva, Brno 2019, p. 82.

32 For example, Order of the Court (Third Chamber) of 7 March 2013, Eva-Maria Painer v. Standard Verlags GmbH and Others (C-145/10). 
touch" on the created work. Therefore, the author must have creative freedom in choosing the elements of the work and their processing (combination). From this creative freedom, it is possible to infer the individuality of the work. For example, in portrait photography, creative freedom in the sense of copyright may consist in the choice of "composition, the position of the photographed person or lighting". When shooting a photographic portrait, the author may also "choose the framing, angle of the image, or atmosphere created". Through these individual creative decisions, the author of the portrait photograph can imprint his "personal touch" ${ }^{33} \mathrm{By}$ a license agreement, a licensor (author, influencer) grants to a licensee (marketer) an authorisation to exercise intellectual property rights (a license) within the stipulated limited or unlimited extent, and a licensee undertakes to pay remuneration to the licensor.

As stated above, if the influencer receives the product and does not make a promotion and does not send the product back, the product might be seen as a gift. By a donation contract, a donor gratuitously transfers the right of ownership in a thing or undertakes to transfer the thing into the ownership of the donee, and the donee accepts the gift or offer.

For all types of contracts, it is not decisive whether the contracts are written or oral.

Besides the private law regulation of influencer marketing, it is necessary to briefly comment on public law regulation, namely hidden advertising. ${ }^{34} \mathrm{The} \mathrm{Eu}-$ ropean backgrounds are set by the Unfair Commercial Practices Directive. ${ }^{35}$ The rules are transposed into national law, especially to public law acts regulating the advertisement and the protection of consumers, and indirectly to private law acts dealing with unfair competition. According to these legal acts, trade practices are always considered deceptive, if the seller is using editorial space in mass media for paid propagation of its product or service and the consumer cannot from its content, pictures or sound unequivocally distinguish, that it is a commercial. Hidden advertising is prohibited by Instagram policies, too. ${ }^{36}$

${ }^{33}$ P. Koukal, op. cit., p. 83.

${ }^{34}$ For more on this topic, including case law, see K. Kůdelíková, op. cit.

${ }^{35}$ Directive 2005/29/EC of the European Parliament and of the Council of 11 May 2005 concerning unfair business-to-consumer commercial practices in the internal market and amending Council Directive 84/450/EEC, Directives 97/7/EC, 98/27/EC and 2002/65/EC of the European Parliament and of the Council and Regulation (EC) no. 2006/2004 of the European Parliament and of the Council (OJ EU L 149/22, 11.06.2005).

${ }^{36}$ Instagram, Instagram Branded Content. Facebook for Business, 26.04.2021, www.face-book. $\mathrm{com} / \mathrm{business} / \mathrm{help} / 523975231703117$ ? id=466037930669828 [access: 26.04 .2021 ]. 


\section{Taxation of Instagram influencers}

No matter the post or video is marked as paid propagation or not, no matter what is the form and type of agreement between the marketer and the influencer, and no matter what is the legal status of the influencer (entrepreneur with a trading license or non-business subject without any license), any income of the influencer is liable to the (personal) income tax. In tax law, this principle is known as the principle of priority of content over form. Moreover, the general anti-abuse rule (GAAR) must be taken into account: for the purposes of calculating the tax liability, an arrangement or a series of arrangements which, having been put into place for the main purpose or one of the main purposes of obtaining a tax advantage that defeats the object or purpose of the applicable tax law, are not genuine having regard to all relevant facts and circumstances, shall be ignored. For these purposes, an arrangement or a series thereof shall be regarded as non-genuine to the extent that they are not put into place for valid commercial reasons which reflect economic reality. ${ }^{37}$

Most of the personal income tax systems worldwide distinguish five possible types of income: incomes from dependent activities (labour law relationships), incomes from independent (business) activities including incomes from intellectual property rights (copyrights), capital incomes, rental incomes, and occasional (irregular) incomes. For the influencers' incomes, capital incomes and rental incomes are out of the question, while the other types of incomes shall be analyzed in detail. All jurisdictions tax both monetary and non-monetary incomes, including barters as used by the marketers and influencers.

\subsection{Taxation of incomes from dependent activities}

Labour law relationships between the marketers and the influencers are rare, namely because the income taxes are generally higher for employees than self-employed persons, and there are additional social and health contributions to be paid by the employer. However, it is necessary to investigate the concrete relationship or concrete contract to decide how to tax the influencer's income: incomes from a relationship where the taxpayer (influencer, employee) must respect the payor's (paying agent's - marketer's, employer's) commands in the course of execution of work for the payor is taxable within the incomes from dependent activities. The dependent work is work performed in relation to the superiority of the employer and the subordination of the employee. The work is performed personally by the employee for the employer, on behalf of the employer, during working hours determined by the employer. The employer organizes and leads the work process and

${ }^{37}$ Council Directive (EU) 2016/1164 of 12 July 2016 laying down rules against tax avoidance practices that directly affect the functioning of the internal market (OJ EU L 193/1, 19/07/2016). 
bears the work's production and economic risk. ${ }^{38}$ Based on these rules, especially (but not only) marketing representation might be seen (if the circumstances are met) as a similar relationship to the labour law relationship if the taxpayer must respect the payor's commands in the course of execution of work for the payor. Among the features decisive for such a determination may be, e.g., preparation of posts and videos by the marketer for the influencer, determining the time of publication of the post, setting hashtags associated with the post, etc.

While the tax rates are worldwide generally the same for the incomes from dependent activities and other types of incomes, other structural components might differ. Especially the construction of the tax base may significantly influence the tax liability. In most countries, the brutto wage is used as a tax base. However, as the employee pays social and health contributions, these contributions are deductible from the tax base in several countries. ${ }^{39}$ Similarly to an entrepreneur, an employee can have expenses incurred to generate, assure, and maintain the income, typically travelling costs to the workplace, working clothes, technical equipment, etc. Some countries (e.g., Austria, Germany, Poland) allow to deduct lump-sum expenses to lower the tax base by a fixed amount of money, by a percent, or in the combination (by a percent up to the fixed amount). ${ }^{40}$ On the other hand, in the Czech Republic, the partial tax base for the incomes from dependent activities was the super gross wage. The super gross wage was defined as income from dependent activity increased by sums of social security and health contributions (pension insurance premiums, contribution to the state employment policy, sickness insurance premiums, and health contribution) that the employer must pay according to special regulations. The social security and health contributions paid by the Czech employer are very high $-33.8 \%$ (34\% till the end of 2019) of the gross income. ${ }^{41}$

\subsection{Taxation of incomes from independent activities}

Most of the influencers tax their incomes as incomes from independent (business) activities. It is not crucial whether they have a trading license or not; black business (without any official permission or registration) is considered business and incomes from black business are liable to tax. The key features for assessing business activity are independence, consistency, performance of activities on own

${ }^{38}$ L. Petríková, Závislá práca a pracovné právo - aktuálny stav, ,Práce a mzdy“ 2019, vol. 14(78), p. 21.

${ }^{39}$ For example, in the Czech Republic until 2007. See M. Radvan, Czech Tax Law, Brno 2020, https:// science.law.muni.cz/knihy/monografie/Radvan_Czech_Tax_Law.pdf [access: 27.04.2021], p. 34.

${ }^{40}$ European Commission, Taxes in Europe Database, https://ec.europa.eu/taxation_customs/ tedb/refineAdvSearch.html [access: 27.04.2021].

${ }^{41}$ For more details, see M. Radvan, Taxation of Employment Income in the Czech Republic, "Kwartalnik Prawa Podatkowego" 2018, vol. 20(1), pp. 23-35. 
behalf, own account, and own responsibility (at own business risk) to achieve profit. All influencers generally follow these circumstances. Mostly, they are entirely free on the marketer when preparing the post. Even if they have a duty to use a specific hashtag or publish the post on a specific date, these limitations are not the obstacles to state that they are independent and their decisions are not influenced by the marketer.

Specific cooperation between the marketer and the influencer might be only one-time or irregular. To investigate the consistency of business activities, it is necessary to examine the influencers' activity for all marketers. According to the technical setting of Instagram concerning displaying posts, it is, in fact, necessary to be active continuously to gain maximal reach. Definitely, when posting on Instagram, influencers perform on their own behalf, own account, and own responsibility. They certainly want to achieve profit; in this regard, it is not decisive if they really make a profit.

As the activities of influences fulfill all conditions to define them as business activities, they should have a trading license. However, it is possible to be an influencer and earn money without any trading license. There are two possibilities: to get incomes from the pursuit of an independent profession or from copyright. The independent profession is a term rarely known in tax law regulation. However, it is used, e.g., by the Czech legislator for non-professional singers, painters, and other artists so that they tax their occasional incomes as incomes from business activities. It is not a systematic method of taxation. Moreover, the term "independent professions" is used in the Czech private law for a specific business without the need for a trading license, such as regulated professions (attornies, notaries, doctors, vets, etc.).

As stated above, most posts and stories result from human creation that falls under creative or artistic activity. That is why it is possible to tax influencers' incomes as incomes from copyright.

For all types of independent activities, the income is to be defined as everything the influencer gets from the marketer, no matter if it is monetary or non-monetary performance. If it is non-monetary performance (including "barters"), mostly the value of products or services is set in the contract or in the communication between the marketer and the influencer. If it is not mentioned there, the value should be set in any other way. The most common is the value of the goods and services as announced by online shops.

The tax base for incomes from independent activities is created by the incomes reduced by the expenses incurred to generate, assure, and maintain income. The most common expenses are technical and graphic equipment (camera, phone, laptop, software, etc.), internet connection costs, travelling costs, costs for the webpage, marketing costs including payments to Instagram to increase the reach of the post and post targeting, special courses, etc. In many countries (e.g., Slovenia, 
Slovakia, the Czech Republic, etc. ${ }^{42}$ ), taxpayers with limited incomes have the right to claim lump-sum expenses instead of real expenses. While in most countries, the lump-sum expenses are relatively low (10-30\% of taxable incomes), in Slovakia, they may reach up to $60 \%$, and in Slovenia and the Czech Republic, up to $80 \%$ of taxable incomes. Lump-sum expenses differ depending on the type of income. For example, in the Czech Republic the influencer with a trading license may claim $60 \%$; however, if she/he gets incomes from the pursuit of an independent profession or from copyright, it is only $40 \%{ }^{43}$

\subsection{Taxation of occasional incomes}

Influencers receiving gifts (as unsolicited product, a gift to the ambassador, unless required by contract) should tax the value of the gift as an occasional income; the value is to be set according to the values as announced by (online) shops. The same rule applies to any other occasional (irregular) income. The advantage is that all states apply a certain non-taxable minimum for the occasional incomes (usually between EUR 1,000-2,000). However, the tax base then includes the incomes reduced by expenses that can be submitted as having been incurred to (only) generate such income, but not to assure and maintain the income, i.e., the expense must be strictly connected with the income generated from concrete activity.

\section{CONCLUSION}

For businesses, social media are crucial in the area of marketing. Besides traditional forms, marketers may use influencers for promotion. Statistics prove that influencer marketing is a growing industry and Instagram has the ambition to become the most popular social network for business promotions.

The article brings the list of legal cooperation contracts between marketers and influencers. The labour law relationships are rare, namely because of higher taxes and contributions and the freedom of influencers to prepare the post or video. There are several possibilities of civil law contracts, mostly innominate contracts, close to a contract of work, or specifically contracts of work. Many posts and stories result from human creation that falls under creative or artistic activity. That is why a license agreement might be used. Rarely donation contracts are used. For all types of contracts, it is not decisive whether the contract is written or oral.

Concerning income taxation of influencers, from the international perspectives, the tax rates may differ a lot: while in Bulgaria, the linear tax rate is $10 \%$, in Austria, Finland, and Sweden, the maximum rates in the progressive tax rates system reach

${ }^{42}$ European Commission, op. cit.

${ }^{43}$ M. Radvan, Czech Tax Law..., p. 35. 
over $50 \%$. All states offer some non-taxable minimums, either as item deductible from the tax base or as a credit (tax relief). There might be different correction components reflecting the social status of the taxpayer (disability, children, marriage, etc.). ${ }^{44}$ In every case, all jurisdictions are taxing influencers' incomes. From the interstate perspective, it will always be necessary to focus on the content of the relationship generating influencer's income, as the principle of priority of content over form must be used, i.e., it is not decisive what is the form and type of agreement between the marketer and the influencer, or what is the legal status of the influencer (entrepreneur with a trading license or non-business subject without any license).

Influencers' incomes might be taxes as incomes from dependent activities if the taxpayer (influencer, employee) must respect the payor's (paying agent's - marketer's, employer's) commands in the course of execution of work for the payor. Among the features decisive for such a determination may be, e.g., preparation of posts and videos by the marketer for the influencer, determining the time of publication of the post, setting hashtags associated with the post, etc. The tax liability is influenced mainly by the construction of the tax base. In most countries, the brutto wage is used as a tax base. In several countries, social and health contributions or lump-sum expenses are deductible from the tax base. On the other hand, in the Czech Republic the partial tax base for the incomes from dependent activities was the super gross wage - the brutto wage increased by sums of social security and health contributions paid by the employer.

Most of the influencers tax their incomes as incomes from independent (business) activities. The key features for assessing business activity are independence, consistency, performance of activities on own behalf, own account, and own responsibility (at own business risk) to achieve profit. As the activities of influences fulfill all conditions to define them as business activities, they should have a trading license. However, it is possible to be an influencer and earn money without any trading license. There are two possibilities: to get incomes from the pursuit of an independent profession or from copyright. The income is to be defined as everything the influencer gets from the marketer, no matter if it is monetary or non-monetary performance, i.e., including barters as used by the marketers and the influencers. The tax base for incomes from independent activities is created by the incomes reduced by the expenses incurred to generate, assure, and maintain income. The most common expenses are technical and graphic equipment, internet connection costs, travelling costs, costs for the webpage, marketing costs, etc. In many countries, taxpayers with limited incomes have the right to claim lump-sum expenses instead of real expenses. The percent differs depending on jurisdiction and the type of income (trading license, independent profession, copyright).

\footnotetext{
${ }^{44}$ European Commission, op. cit.
} 
Gifts as unsolicited products, gifts to the ambassador, unless required by contract, and other occasional (irregular) incomes should be taxed as an occasional income. Most jurisdictions offer a certain non-taxable minimum. The tax base often includes the incomes reduced by expenses that can be submitted as having been incurred to (only) generate such income, but not to assure and maintain the income.

As evident, the tax liability is influenced only by the tax base. The tax rate and other structural components of the tax remain the same for different types of incomes. Generally, it is always better for the influencer to have a trading license (to be a businessman) than tax his/her incomes as incomes from copyright. Incomes from dependent activities based on labour law contract or occasional incomes are not probable for a typical influencer, and still, the taxation in this way is not really favourable. Even if some authors ${ }^{45}$ argue that it is necessary to amend the national legal regulation to make the influencers' income taxation more transparent and fair, de lege lata regulation, at least in all developed countries, is in the author's opinion convenient. There is no need to adopt new specific tax law norms to tax influencers' incomes properly. The hypothesis stated in the introduction is confirmed. However, it must be stated that it is relatively difficult for the tax offices to identify both the influencers with the tax duties and their taxable incomes. In every case, the taxpayers have a duty to file the tax return and pay the tax under the self-application principle. However, most of them do not do this and the activity of the tax office should follow. To find the taxpayers, it is possible to ask Instagram to pass the list of influencers with marketing activities using the tools in tax procedural codes. To identify the incomes, it would be necessary to go through the Instagram profile and contact the marketers to present the contracts or invoices.

\section{REFERENCES}

\section{Literature}

Casaló L.V., Flavián C., Ibáñez-Sánchez S., Influencers on Instagram: Antecedents and Consequences of Opinion Leadership, "Journal of Business Research" 2020, vol. 117(9),

DOI: https://doi.org/10.1016/j.jbusres.2018.07.005.

Cotter K., Playing the Visibility Game: How Digital Influencers and Algorithms Negotiate Influence on Instagram, "New Media and Society" 2019, vol. 21(4),

DOI: https://doi.org/10.1177/1461444818815684.

De Veirman M., Cauberghe V., Hudders L., Marketing through Instagram Influencers: The Impact of Number of Followers and Product Divergence on Brand Attitude, "International Journal of Advertising” 2017, vol. 36(5), DOI: https://doi.org/10.1080/02650487.2017.1348035.

Kostikidis S., Influencer Income and Tax Treaties, "Bulletin for International Taxation" 2020, vol. 74(6).

${ }^{45}$ S. Şekeroğlu, S. Bilgin, op. cit., p. 131. 
Koukal P., Autorské právo, public domain a lidská práva, Brno 2019.

Kůdelíková K., Skrytá reklama na sociálních sitich-diplomová práce, Brno 2020.

Molenaar D., Grams H., Influencer Income and Tax Treaties, "Bulletin for International Taxation" 2020, vol. 74(9).

Petríková L., Závislá práca a pracovné právo - aktuálny stav, „Práce a mzdy“ 2019, vol. 14(7-8).

Radvan M., Taxation of Employment Income in the Czech Republic, "Kwartalnik Prawa Podatkowego" 2018, vol. 20(1).

Şekeroğlu S., Bilgin S., Influencer Marketing and Taxation of Influencer in Turkey, [in:] New Trends in Social Sciences, eds. H. Özüdoğru, T. Çetin, H. Kara, Klaipeda 2019.

\section{Netography}

Bern T., Social Media Trends Report: Key Insights From Q3 2020, www.socialbakers.com/blog/ social-media-trends-report-q3-2020 [access: 19.04.2021].

Bern T., State of Influencer Marketing Report: Effects of Coronavirus, www.socialbakers.com/blog/ influencer-marketing-report [access: 19.04.2021].

Droesch B., Instagram's New Explore Ads Signal Potential Changes to Organic Reach, 9.07.2019, www.emarketer.com/content/instagrams-new-explore-ads-signal-potential-changes-to-organic-reach [access: 19.04.2021].

European Commission, Taxes in Europe Database, https://ec.europa.eu/taxation_customs/tedb/refineAdvSearch.html [access: 27.04.2021].

Facebook for Business, How Instagram Boosts Brands and Drives Sales, 6.02.2019, www.facebook. $\mathrm{com} /$ business/news/insights/how-instagram-boosts-brands-and-drives-sales [access: 19.04.2021].

Facebook for Business, How to Take Your Instagram Content to the Next Level, 14.02.2019, www. facebook.com/business/news/insights/how-to-take-your-instagram-content-to-the-nextlevel?ref=FBB_ConnectWithNewAudiences [access: 16.04.2021].

Ghatt J., Report: Top Brands Spent \$255M on Influencers with Fake Engagement, 5.03.2020, https:// jenebaspeaks.com/2020/03/report-top-brands-spent-255m-on-influencers-with-fake-engagement [access: 19.04.2021].

Hopper HW, Instagram Rich List 2020, 19.04.2021, www.hopperhq.com/blog/instagram-rich-list [access: 19.04.2021].

HubSpot, Instagram Engagement Report - What Your Company Needs to Know for 2020, 10.03.2021, https://cdn2.hubspot.net/hubfs/53/HubSpotMention_ebook_2020-FINAL-1.pdf [access: 19.04.2021].

Influencer Marketing Hub, The State of Influencer Marketing 2020: Benchmark Report, 14.02.2021, https://influencermarketinghub.com/influencer-marketing-benchmark-report-2020 [access: 19.04.2021].

Instagram, Instagram Branded Content. Facebook for Business, 26.04.2021, www.face-book.com/ business/help/523975231703117?id=466037930669828 [access: 26.04.2021].

Iqbal M., Instagram Revenue and Usage Statistics (2021), 24.05.2021, www.businessofapps.com/ data/instagram-statistics [access: 16.04.2021].

Kemp S., Digital 2020: October Global Statshot, 20.10.2020, https://datareportal.com/reports/digital-2020-october-global-statshot [access: 16.04.2021].

McClendon A., It's estimated that Fashion Nova spent \$40M on influencer marketing last year, 2.03.2020, https://twitter.com/faintflex/status/1234272114808696834?ref_src=twsrc\%5Etfw\%7Ctwcamp\%5Etweetembed\%7Ctwterm\%5E1234272114808696834\%7Ctwgr\%5E\%7Ctw con $\% 5$ Es 1_\&ref_url=https $\% 3 \mathrm{~A} \% 2 \mathrm{~F} \% 2 \mathrm{Fwww} . c o m p l e x . c o m \% 2 \mathrm{Fstyle} \% 2 \mathrm{~F} 2020 \% 2 \mathrm{~F} 03 \% 2 \mathrm{~F}-$ fashion-nova-spent-40-million-dollars-influencer-marketing-2019 [access: 19.04.2021]. 
Mediakix, The Influencer Marketing Trends to Know for 2021, 17.04.2021, https://mediakix.com/ influencer-marketing-resources/influencer-marketing-trends [access: 19.04.2021].

Radvan M., Czech Tax Law, Brno 2020, https://science.law.muni.cz/knihy/monografie/Radvan Czech_Tax_Law.pdf [access: 27.04.2021].

Social Blade, Top 50 Instagram Business Accounts Sorted by Followers, https://socialblade.com/ instagram/top/50 [access: 19.04.2021].

Takumi, Into the Mainstream: Influencer Marketing in Society, https://takumi.com/whitepaper2020 [access: 19.04.2021].

\section{Legal acts}

Council Directive (EU) 2016/1164 of 12 July 2016 laying down rules against tax avoidance practices that directly affect the functioning of the internal market (OJ EU L 193/1, 19/07/2016).

Directive 2005/29/EC of the European Parliament and of the Council of 11 May 2005 concerning unfair business-to-consumer commercial practices in the internal market and amending Council Directive 84/450/EEC, Directives 97/7/EC, 98/27/EC and 2002/65/EC of the European Parliament and of the Council and Regulation (EC) no. 2006/2004 of the European Parliament and of the Council (OJ EU L 149/22, 11.06.2005).

\section{ABSTRAKT}

W niniejszym artykule omówiono kwestie związane z opodatkowaniem influencerów korzystających z serwisu społecznościowego Instagram. Głównym celem było ustalenie sposobu, w jaki należy opodatkować dochody influencerów. Celem pośrednim dla osiągnięcia tego podstawowego celu było sporządzenie listy umów o współpracy pomiędzy specjalistami od marketingu a influencerami. Potwierdzono hipotezę o braku potrzeby uchwalania nowych norm prawa podatkowego dla prawidłowego opodatkowania dochodów influencerów, przynajmniej w krajach rozwiniętych. Wszystkie systemy prawne opodatkowują dochody influencerów. Trzeba zawsze koncentrować się na treści stosunku generującego dochód influencera, gdyż należy stosować zasadę pierwszeństwa treści nad formą. Należność podatkowa wynika jedynie z podstawy opodatkowania. Stawka podatku i inne elementy składowe podatku są takie same dla różnych rodzajów dochodu. Co do zasady rejestracja działalności gospodarczej jest dla influencera zawsze lepszym rozwiązaniem niż opodatkowanie dochodów z praw autorskich. Dochody z niezależnej działalności w oparciu o umowę o pracę lub dochody okazjonalne są dość rzadkie dla typowego influencera, a opodatkowanie w ten sposób nie jest w istocie korzystne. Nowatorski charakter przedstawionych badań polega na tym, że dotychczas w żadnych opublikowanych artykułach naukowych nie poruszono przedmiotowej tematyki. W opinii autora artykuł ma wartość poznawczą, zarówno naukową, jak i praktyczną.

Słowa kluczowe: prawo podatkowe; opodatkowanie; prawa autorskie; dochód; influencer; Instagram 